\title{
ESTIMASI EROSI DAN SEDIMENTASI LAHAN PADA DAS LANGSA BERBASIS SISTEM INFORMASI GEOGRAFIS (SIG)
}

\author{
Faiz Isma $^{1)}$, Meilandy Purwandito ${ }^{2)}$,Zacky Ardhyan ${ }^{3)}$ \\ Program Studi Teknik Sipil, Universitas Samudra, Meurandeh-Langsa-Aceh, \\ Indonesia \\ Email:faizisma.ts@unsam.ac.id ${ }^{1)}$,meilandy@unsam.ac.id ${ }^{2)}$, \\ zackyardhyan82@gmail.com ${ }^{3)}$
}

DOI: http://dx.doi.org/10.29103/tj.v9i1.169

\begin{abstract}
Abstrak
DAS Langsa terus mengalami kerusakan lingkungan akibat perubahan tutupan lahan. Kerusakan lingkungan mempengaruhi besaran erosi pada DAS dikarenakan pada saat hujan menghasilkan energi kinetik membawa butiran tanah yang disalurkan menuju lahan terendah, tetapi proses pengangkutan erosi berpengaruh terhadap kerapatan vegetasi dan lereng lahan yang dilintasinya, semakin besar nilai kerapatan vegetasi lahan maka penyaluran erosi akan semakin mudah dan cepat. Penelitian ini mempunyai tujuan untuk mengestimasi besaran erosi dan sedimentasi lahan menggunakan persamaan USLE dan persamaan Vestraten 2007 dengan menyajikan estimasi menggunakan SIG. Hasil analisa menyatakan bahwa tingkat bahaya erosi (TBE) pada DAS Langsa masuk dalam kategori sedang dan proses penyaluran erosi dari tiap unit lahan berdasarkan arah aliran menghasilkan sedimentasi lahan yang tertinggi sebesar 908,39 ton/ha/tahun dan umumnya berada pada bagian hulu DAS dan yang paling rendah berada sub DAS bagian hilir sebesar 3,447 ton/ha/tahun dan bahkan ada beberapa sub DAS tidak terjadi sedimentasi lahan seluas 2.944,63 ha dan volume erosi yang tersalurkan di estuari kuala langsa sebesar $10.512,25 \mathrm{~m}^{3} /$ tahun sebagai penyebab pendangkalan disepanjang alur estuari kuala langsa.
\end{abstract}

Kata Kunci: Erosi Lahan, kapasitas angkutan sedimen, sedimentasi lahan dan SIG

\begin{abstract}
The watershed of Langsa has been continuously experienced environmental damage due to changes in land cover. Environmental damage affects the amount of erosion in the watershed. Kinetic energy produced by rain brings the grain of soil to the lowest land. Because transporting process of erosion affects the vegetation density and the slope of the land when passes, a study to identify the potential erosion of Langsa watershed is essensial to estimate the distribution of erosion into the Langsa estuary. This study is aimed to estimate the amount of potential erosion in the Krueng Langsa watershed using GIS. The results of the analysis state that the erosion hazard level (TBE) in the Langsa watershed falls into the moderate category and the erosion distribution process of each land unit based on flow direction produces the highest land sedimentation of 908.39 tons / ha / year and is generally in the upstream watershed the lowest is in the downstream sub-watershed of 3,447 tons / ha / year and even some sub-watersheds do not occur sedimentation area of 2,944.63 ha and the volume of erosion channeled in the estuary is $10,512.25 \mathrm{~m}^{3} /$ year as the cause of the estuary silt of kuala langsa.
\end{abstract}

Keywords: Land Erosion, sediment transport capacity, land sedimentation and GIS

Estimasi Erosi Dan Sedimentasi Lahan Pada Das Langsa Berbasis Sistem Informasi 


\section{Latar Belakang}

Umumnya lahan bumi mengalami erosi akibat benturan air hujan dalam kategori mengkhawatirkan (Suripin, 2002) dengan kisaran erosi rata - rata 20 - 40 ton/ha/tahun dengan jangka waktu 150 tahun lapisan tanah atas akan habis, sehingga salah satu masalah serius dalam kerusakan lingkungan terhadap lahan dipermukaan bumi menyebabkan berkurangnya kemampuan tanah dalam mendukung produktivitas pada Daerah Aliran Sungai atau DAS (Hasibuan, 2009). DAS Langsa merupakan bagian dari WS tamiang - langsa di mana DAS nya mencakup kota langsa yang terus mengalami perkembangan akibat penyediaan sarana dan prasarananya sebagai penunjang kegiatan perdagangan, industri dan administrasi pemerintahan kota langsa. Pada dasarnya pertumbuhan jumlah manusia yang terus meningkat menyebabkan meningkatnya kebutuhan akan perubahan tutupan lahan. Interaksi manusia dengan DAS akan berdampak pada kualitas ekosistem DAS menurun, khususnya pada kualitas dan kuantitas airnya.

Kerusakan lingkungan DAS akan menimbulkan dampak terhadap erosi terutama musim hujan lapisan permukaan tanah bagian atas diangkut dan tersalurkan ke bagian hilir (estuary) menyebabkan berkurangnya kapasitas akibat pendangkalan, di mana estuari kuala Langsa dahulu terdapat aktivitas pelayanan alur pelabuhan sebagai tempat berlabuhnya kapal yang mampu menyandarkan kapal bermuatan 5000 DWT, Panjang 160 m dan draft kapal 9.0 m (Tim Teknis AMDAL Khusus, 2007), tetapi saat ini kondisi alur pelayaran mengalami pendangkalan akibatnya kapal tidak bisa merapat ke dermaga, Hal ini dibuktikan dengan kejadian minggu, 10 Desember 2017 di mana kapal rumah sakit KRI dr. Soeharso dalam rangka Operasi Bhakti Sosial TNI AL Surya Bhaskara Jaya ke 66 di kota Langsa tetapi tidak bisa merapat di dermaga pelabuhan kuala langsa menyebabkan kegiatan layanan kesehatan dilaksanakan di tengah laut (Redaksi, 2018), salah satu penyebab pendangkalan di estuari bersumber dari sedimen yang berasal dari hulu DAS akibat erosi lahan dan tebing sungai namun lahan tererosi tidak semua akan disalurkan ke hilir disekitar DAS tetapi sebagian akan mengalami sedimentasi lahan secara langsung akibat vegetasi lahan dan beda tinggi lereng yang menghambat pengangkutan erosi tersebut (Isma, 2014), maka perlu dilakukan suatu studi dalam memprediksi potensi erosi, sedimentasi lahan dan penyaluran erosi ke hilir (estuari) yang terjadi pada DAS Langsa agar memperoleh pengetahuan yang penting dan informasi yang akurat, mutakhir, dan relevan dapat dibangun dengan sistem informasi geografis (SIG).Tujuan dari penelitian ini adalah mengestimasi potensi erosi dan sedimentasi lahan pada DAS Langsa serta memberikan informasi terhadap besaran erosi yang masuk ke estuari yang akan menjadi sedimentasi.

\section{Metode Penelitian}

\subsection{Erosi Lahan}

Persamaan yang dipakai dalam mengestimasi erosi adalah USLE (Universal Soil Loss Equation) (Wischmer and Smith, 1978):

$$
E=R \times K \times L S \times C \times P
$$


Keterangan:

$$
\begin{aligned}
& \mathrm{E}=\text { jumlah tanah tererosi (ton/ha/tahun); } \\
& \mathrm{R}=\text { erosivitas hujan tahunan }(\mathrm{MJ} \mathrm{mm} / \mathrm{ha} / \mathrm{jam} / \mathrm{tahun}) ; \\
& \mathrm{K}=\text { erodibilitas tanah (ton.ha.jam/ } \mathrm{MJ} / \mathrm{mm} / \mathrm{ha}) ; \\
& \mathrm{LS}=\text { indeks panjang dan kemiringan lereng (dimensionless); } \\
& \mathrm{C}=\text { indeks tutupan lahan (dimensionless); } \\
& \mathrm{P}=\text { indeks upaya konservasi tanah (dimensionless). }
\end{aligned}
$$

Hasil perhitungan dengan metode USLE menghasilkan suatu dugaan erosi tanah di setiap satuan lahan pada DAS, selanjutnya nilai erosi tiap unit lahan dikelompokkan 5 kriteria kelasifikasi erosi lahan dengan kelas I kategori sangat rendah yaitu < 15 ton/ha/tahun, kelas II kategori rendah yaitu 15 - 60 ton/ha/tahun, kelas III kategori sedang yaitu 60 - 180 ton/ha/tahun, kelas IV kategori berat yaitu 180 - 480 ton/ha/tahun, kelas V kategori sangat berat yaitu > 480 ton/ha/tahun.

Menurut peraturan menteri Kehutanan tahun 2009 bahwa berdasarkan kedalaman tanah efektif (solum tanah) dan klasifikasi tingkat besaran erosi pada suatu unit lahan dapat menentukan tingkat bahaya erosi (TBE) yang memberikan batasan toleransi erosi unit lahan yang masih dapat diizinkan berkisar $<10$ ton/ha/tahun (Arsyad.S, 1989).

\subsection{Faktor erosivitas hujan (R)}

Persamaan Lenvain dalam Peraturan Menteri Kehutanan RI, Nomor: P. 32/MENHUT-II/2009 sebagai berikut:

$$
R_{m}=2,21(\text { Rain })_{m}{ }^{1,36}
$$

Untuk memperoleh nilai $\mathrm{R}$ dihitung dengan menggunakan persamaan berikut:

$$
R=\sum_{m=1}^{12} R_{m}
$$

Keterangan:

$\mathrm{Rm}=$ Jumlah curah hujan bulanan, (Rain) $\mathrm{m}$ adalah curah hujan bulanan $(\mathrm{cm})$;

\subsection{Faktor Erodibilitas Tanah $(\mathbf{K})$}

Suatu tanah yang memiliki erodibilitas rendah kemungkinan bisa mengalami erosi berat jika tanah berada pada lereng yang curam dan panjang dengan intensitas hujan tinggi. Sebaliknya tanah yang memiliki erodibilitas tinggi kemungkinan bisa mengalami erosi ringan atau bahkan tidak sama sekali bila terdapat pada pada lereng yang datar, hal ini juga tidak lepas dari faktor penutupan vegetasi lahan yang baik dan intensitas hujan rendah. Besarnya nilai $\mathrm{K}$ ditentukan dengan persamaan Wischmeier dan Smith, 1978 dalam (Tingkat et al., 2013) berikut ini.

$$
K=\frac{1,292 M^{1,14}\left(10^{-4}\right)(12-a)+3,25(b-2)+2,5(c-3)}{100}
$$


Keterangan:

$\mathrm{M}=$ Ukuran butiran tanah yang didapat dari $(\%$ debu $+\%$ pasir sangat halus) (100 - \% Liat);

$\mathrm{a}=\%$ bahan organik (\% $\mathrm{C} \times 1,724)$

$\mathrm{b}=$ Klasifikasi struktur tanah;

$\mathrm{c}=$ kelasifikasi permeabilitas tanah.

Persamaan bisa diterapkan pada persentasi kandungan debu dan pasir sangat halus kurang dari $70 \%$. Jika lebih dari $70 \%$ maka penentuan indeks erodibilitas tanah dilakukan menggunakan nomograph juga ditentukan oleh Wischmeier dan Smith 1978. Kemudian dilakukan interpolasi (IDW) dengan QGIS 2.18 untuk menentukan sebaran indeks K pada DAS Langsa.

\subsection{Faktor kemiringan lereng (LS)}

Kemiringan dan panjang lereng adalah dua unsur topografi yang paling berpengaruh terhadap aliran permukaan dan erosi. Unsur lain yang mungkin berpengaruh adalah konfigurasi, keseragaman dan arah lereng. Semakin miring suatu lahan dan semakin panjang lereng maka erosi akan semakin besar. Semakin miring suatu lahan dan semakin panjang lereng maka erosi akan semakin besar. Kemiringan lereng di Analisa menggunakan data Digital Elevation Model (DEM) dari website: https://earthexplorer.usgs.gov/ selanjutnya di analisa menggunakan perangkat lunak Sistem Informasi Geografis yaitu QGIS 2.18 sesuai dengan rincian klasifikasi kemiringan lereng $(\%)$ dengan kelas I $(0-8 \%)$ kategori datar, kelas II (> 8 - 15\%) kategori landai, kelas III (> $15-25 \%)$ kategori agak curam, kelas IV (> $25-45 \%)$ kategori curam, dan kelas V (> $45 \%)$ kategori sangat curam (Asdak, 1995).

\subsection{Faktor tutupan lahan (landuse) dan konservasi tanah (P)}

Faktor tutupan lahan (C) ditunjukan sebagai angka perbandingan yang berhubungan dengan tanah hilang tahunan pada areal yang bervegetasi dengan areal yang sama, jika suatu area kosong dan ditanami secara teratur, maka niilai faktor $\mathrm{C}$ berkisar antara 0,001 pada hutan tak terganggu hingga 1,0 pada tanah kosong yang tidak ditanami. Pada kondisi tidak ada usaha pengendalian erosi, diberikan nilai $\mathrm{P}$ sama dengan 1 dan kurang dari 1 untuk penggunaan lahan dengan penangan secara mekanis (Hasibuan, 2009). penentuan nilai indeks tutupan lahan (landcover) sukar dilakukan akan tetapi ada beberapa ahli telah memberikan besaran indeks tutupan lahan yaitu belukar rawa $(C=0,010)$, rawa $(\mathrm{C}=0,010)$, semak/belukar $(\mathrm{C}=0,300)$, pertanian lahan kering campur $(\mathrm{C}=$ $0,190)$, pertanian lahan kering $(\mathrm{C}=0,280)$, perkebunan $(\mathrm{C}=0,50)$, pemukiman $(\mathrm{C}=0,950)$, hutan lahan kering skunder, mangrove skunder, dan rawa sekunder $(\mathrm{C}=0,010)$, sawah $(\mathrm{C}=0,010)$, tambak $(\mathrm{C}=0,001)$, dan tanah terbuka $(\mathrm{C}=$ 0,950) (Rauff, 2011).

\subsection{Sedimentasi lahan}

Menurut Foster dan Meyer (1977) menyatakan bahwa erosi sebagai penyebab timbulnya sedimentasi yang disebabkan oleh air meliputi proses pelepasan (detachment), penghanyutan (transportation), pengendapan 
(deposition), dan sedimentasi dari partikel tanah yang terjadi akibat tumbukan air hujan. (Jain.K.M, 2010). Meyer dan wischmeier menggambarkan proses pengaliran erosi tanah dari hulu menuju hilir dengan bantuan grid unit DAS yang berakhir pada outlet dibagian hilir. Penyaluran sedimen dari hulu DAS menuju hilir DAS (Outlet) dilakukan dengan membuat suatu grid unit DAS biasanya berupa pertemuan antara dua atau lebih aliran anak sungai berpedoman pada arah aliran (flow direction) sebagai arah penyaluran erosi terbawa akibat aliran menuju grid unit yang terdekat dan berakhir di outlet dapat dilihat pada Gambar 2. Erosi lahan yang terjadi di suatu grid tidak semuanya tersalurkan ke grid terdekat melainkan ada erosi akan menjadi sedimentasi lahan sebagai pembaharuan tanah, adapun besaran erosi yang disalurkan dari grid dipengaruhi akibat sebaran vegetasi dan lerengnya berdasarkan besaran kapasitas angkutan sedimen (persamaan 5) sebagai penyaluran erosi meninggalkan grid dan sisanya akan menjadi sedimentasi lahan di unit lahan tersebut.

Verstraten, dkk 2007 memberikan persamaan untuk memprediksi kapasitas angkutan sedimen di suatu lahan adalah sebagai berikut. (Thomas, Joseph and Thrivikramji, 2017)

$$
T C_{i}=K_{T C_{i}} R_{i} K_{i} A_{s i}^{1,44} S_{i}^{1,44}
$$

Keterangan:

$\mathrm{K}_{\mathrm{TCi}}=$ Koefisien kapasitas angkutan sedimen ( $\left.\mathrm{kg} / \mathrm{ha} / \mathrm{tahun}\right)$;

$\mathrm{I} \quad=$ Iterasi tiap grid; $\mathrm{S}_{\mathrm{i}}=$ Sebaran gradien lereng;

$\mathrm{A}_{\mathrm{Si}} \quad=$ Penampang sebaran lereng;

Koefisien vegetasi merupakan kerapatan vegetasi di setiap grid berdasarkan Normalized difference vegetation index (NDVI) diperoleh dari pengolahan sinyal digital data yaitu lansat 8 di mana nilai kecerahan berdasarkan kanal data sensor satelit. NDVI pada dasarnya membandingkan antara kanal infranerah (band 5) dan kanal inframerah dekat (band 4) sehingga diperoleh fenomena penyerapan cahaya merah (infranerah) dan pemantulan cahaya merah dekat (nearinfranerah) oleh klorofil membuat nilai kecerahan yang diterima sensor satelit akan jauh berbeda. Dengan konsep ini maka dikembangkannya suatu algoritma indeks vegetasi (Rouse et al., 1973) yaitu,

$$
N D V I=\frac{N I R-V R}{N I R+V R}=\left(\frac{\text { band } 5-\text { band } 4}{\text { band } 5+\text { band } 4}\right)
$$

Indeks vegetasi mempunyai nilai minimum yakni -1 dengan kondisi wilayah tidak bervegetasi. Sebaliknya bahwa indeks vegetasi yang memiliki nilai 1 menunjukkan bahwa kondisi wilayah bervegetasi. Kapasitas angkutan sedimen $\left(\mathrm{K}_{\mathrm{TC}}\right)$ ditentukan dengan indeks NDVI yaitu membuat fungsi matematis berupa eksponensial dari NDVI dalam memperkirakan sebarannya di suatu DAS (Jain.K.M, 2010).

$$
K_{T C_{i}}=\beta * \exp \left[\frac{-N D V I}{1-N D V I}\right]
$$

Nilai $\beta$ adalah normalisasi kalibrasi berdasarkan indeks vegetasi; Nilai $\beta=1$ berdasarkan hasil penelitian terdahulu menunjukkan hubungan normal dari NDVI terhadap kapasitas angkutan sedimen $\left(\mathrm{K}_{\mathrm{TC}}\right)$ (Van Der Knijff, Jones and Montanarella, 1999). 
Berdasarkan Meyer dan Wischmeier 1969 (Jain.K.M, 2010; Thomas, Joseph and Thrivikramji, 2018) menyatakan:

a. jika besaran erosi tanah (SE) yang terjadi lebih besar dari kapasitas angkutan sedimen $\left(\mathrm{TC}_{\mathrm{i}}\right)$ pada area grid hulu, maka akan terjadi endapan (D) pada grid sebesar:

$$
D i=S E i-T C i
$$

Maka erosi yang tertinggal sama dengan endapan yang terjadi pada grid (SE = D). Angkutan sedimen keluar $\left(\mathrm{T}_{\text {outi }}\right)$ yang keluar melalui alur ke grid hilir yang terdekat sesuai dengan alur angkutan sebesar:

$$
T_{\text {outi }}=T C
$$

Angkutan sedimen yang keluar dari grid hulu tersebut akan bergabung menjadi besaran erosi tanah pada grid hilir yang terkoneksi berdasarkan alur yang direncanakan, maka total erosi tanah pada grid hilir adalah:

$$
S E_{\text {hilir }}=S E i_{(\text {hilir })}+\sum T_{\text {outi (hulu })}
$$

b. jika besaran erosi lahan (SE) yang terjadi lebih kecil dari kapasitas angkutan sedimen $\left(\mathrm{TC}_{\mathrm{i}}\right)$ pada area grid hulu, maka akan tidak terjadi endapan (D) atau erosi akan keluar semua dari grid:

$$
D i=0
$$

Angkutan sedimen keluar ( $\mathrm{T}_{\text {outi }}$ ) yang keluar melalui alur ke grid hilir yang terdekat sesuai dengan alur angkutan sebesar:

$$
T_{\text {outi }}=S E_{i}
$$

Angkutan sedimen yang keluar dari grid hulu tersebut akan bergabung menjadi besaran erosi tanah pada grid hilir berdasarkan arah aliran (flow direction), maka total erosi tanah pada grid hilir yang tersalurkan adalah:

$$
\sum S E_{\text {Hilir }}=S E_{\text {i(hilir })}+\sum T_{\text {outi(hulu })}
$$

\section{Hasil dan Pembahasan}

Penelitian dilakukan secara eksploratif kuantitatif dan kualitatif. Artinya data-data penelitian diolah secara kuantitatif menggunakan persamaan-persamaan yang relevan dan hasilnya dijelaskan secara kualitatif. Kemudian kesimpulan diambil secara induktif yang artinya poin-poin pengamatan lapangan dan analisa data akan menghasilkan pemodelan potensi erosi

Daerah aliran sungai krueng langsa memiliki luas sebesar 23.581,01 Ha di mana secara geografis DAS Krueng Langsa pada bagian hilir berada pada posisi $98^{0} 01^{\prime} 58,8^{\prime \prime} \mathrm{BT}-4^{0} 32$ ' $38,4^{\prime \prime}$ LU dan $98^{0} 03^{\prime} 7,2^{\prime \prime}$ BT $-4^{0} 31^{\prime} 26,4^{\prime \prime}$ LU dan bagian hulu berada pada posisi $97^{0} 51^{\prime} 46,8^{\prime \prime} \mathrm{BT}-4^{0} 25^{\prime} 8,4^{\prime \prime} \mathrm{LU}$ dan $97^{0} 58^{\prime}$ 26,4” BT $-4^{0} 19$ ' 30" LU

\subsection{Unit Lahan}

Peta dasar DAS langsa diperoleh dari Balai Pengelolaan Daerah Aliran Sungai krueng Aceh (BPDAS Krueng Aceh) Provinsi Aceh, peta dasar sebagai pedoman dalam pemotongan data DEM dianalisa dengan perangkat lunak SIG yaitu ARCGIS versi 10.3 melalui perintah Arctoolbox $\rightarrow$ Spatial Analys Tools $\rightarrow$ Hydrology (peta raster DEM SRTM mengahsilkan peta raster fill, flow accumulation, flow direction, dan stream order) $\rightarrow$ Watershead akan menghasilkan suatu luasan sub DAS sebagai unit lahan berdasarkan pertemuan 
dua atau lebih aliran (stream order) dari hulu ke hilir dari DAS melalui arah aliran (flow direction). Peta unit lahan ini berfungsi sebagai pemisah dari bagian lahan pada DAS Langsa.

Perubahan tutupan lahan yang mengalami peningkatan berada pada lahan perkebunan terjadi dari tahun 2015 ke tahun 2016 sebesar 14,98 \% dan lahan permukiman mengalami peningkatan dari tahun 2015 sebesar 9,02\%, tahun 2016 sebesar $0,55 \%$, dan tahun 2017 sebesar 0,03\% kejadian ini dikarenakan pesatnya pembangunan di kota Langsa terutama perkembangan perumahan bersubsidi (Redaksi, 2018) dan pemanfaatan lahan sebagai perkebunan masyarakat. Sedangkan penurunan luas tutupan lahan dialami pertanian lahan kering semak pada tahun 2015 sebesar 6,09 \%, tahun 2016 sebesar 10,67\% dan pertanian lahan kering sebesar 3,38\%. Faktor sebaran kemiringan lereng (LS) DAS Langsa diperihatkan pada Tabel 1.

Tabel 1. Sebaran kemiringan lereng (LS)

\begin{tabular}{ccccc}
\hline $\begin{array}{c}\text { Kemiringan } \\
\text { Lereng }\end{array}$ & Keterangan & Nilai LS & Luas $(H a)$ & $\begin{array}{c}\text { Persentasi } \\
(\%)\end{array}$ \\
\hline $0-8 \%$ & Datar & 0,4 & $15.880,09$ & 67,34 \\
\hline$>8-15 \%$ & Landai & 1,4 & $3.558,23$ & 15,09 \\
\hline$>15-25 \%$ & Agak Curam & 3,1 & $2.628,64$ & 11,15 \\
\hline$>25-45 \%$ & Curam & 6,8 & $1.477,94$ & 6,27 \\
\hline$>45 \%$ & Sangat Curam & 9,5 & 36,12 & 0,15 \\
\hline & Total & & $\mathbf{2 3 . 5 8 1 , 0 1}$ & $\mathbf{1 0 0}$ \\
\hline
\end{tabular}

Sebaran kemiringan lereng (LS) pada DAS krueng Langsa pada Gambar 5 menerangkan sebaran lereng datar (0-8\%) memiliki luas $15.880,09$ ha atau 67,34 $\%$ dari luas total, disusul daerah landai $(>8-15 \%)$ memiliki luas $3.558,23$ ha $(15,09 \%)$, daerah agak curam sebesar $1.477,94$ ha $(11,15 \%)$, daerah curam sebesar $1.477,94$ ha $(6,27 \%)$, dan daerah sangat curam sebesar 36,12 ha atau 0,15 $\%$ sebagai daerah yang memiliki sebaran lereng yang paling kecil di DAS Langsa.

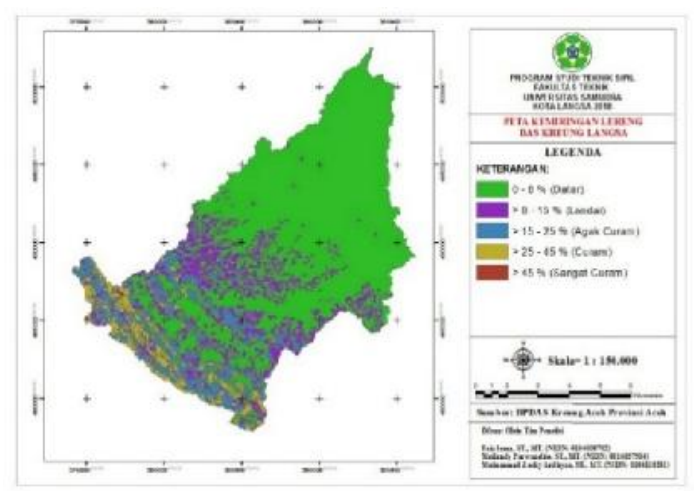

Gambar 5. Peta sebaran kemiringan lereng (LS)

Pada Gambar 5 menerangkan kondisi sebaran kemiringan lereng pada DAS krueng Langsa di mana daerah datar paling dominan berada pada bagian hilir DAS, sedangkan kondisi landai, agak curam, curam, dan sangat curam berada pada bagian hulu DAS krueng Langsa. Faktor erodibilitas tanah pada lahan DAS dilakukan dengan menganalisa sampel tanah dengan mengambil perwakilan tanah 
dari bagian hulu (desa Kemuning hulu dan desa kemuning), bagian tengah (desa timbang langsa, desa tengoh, desa bukit meutuah dan desa meurandeh), dan bagian hilir (desa cinta raja dan desa kuala langsa), di mana pengambilan titik sampel tanah dan sebaran tekstur tanah DAS terlihat pada Gambar 6.

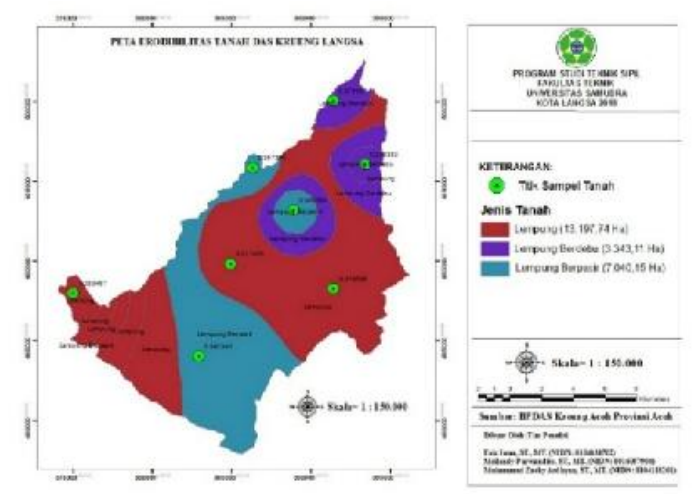

Gambar 6. Peta sebaran erodibilitas tanah (K)

Dari hasil analisa diperoleh sebaran jenis tanah DAS Langsa dengan tekstur tanah lempung seluas $13.197,74$ ha $(55,96 \%)$, lempung berpasir seluas $3.343,74$ ha $(14,18 \%)$ dan lempung berdebu seluas $7.040,15$ ha $(29,86 \%)$ di mana berat jenis tanah $(\mathrm{G})=2,66$ ton $/ \mathrm{m}^{3}$ dan kelas permeabilitas tanah $(\mathrm{P})$ berada pada kelas 3 (sedang) dan kelas 4 (sedang sampai lambat) juga menggambarkan proses infiltrasi dari tanah dalam menerima aliran tergolong sedang. Sebaran indeks erodibilitas tanah DAS krueng Langsa pada bagian hulu lebih kecil dibandingkan bagian hilir yaitu 0,283 bagian hulu berada pada desa kemuning hulu dengan kategori sedang dan 0,373 bagian hilir berada pada desa kuala Langsa dengan kategori agak tinggi dalam mengasilkan besaran erosi lahan.

\subsection{Sebaran Tingkat Bahaya Erosi (TBE)}

Proses penentuan sebaran tingkat bahaya erosi (TBE) dengan melakukan overlay setiap peta - peta yang dihasilkan dari faktor erosi kemudian informasi dari faktor erosi dianalisa sesuai dengan USLE pada persamaan (1) menghasilkan sebaran potensi erosi, selanjutnya melakukan homogenitas potensi erosi di setiap unit lahan berdasarkan luasan sub DAS dari hulu hingga hilir DAS krueng Langsa. Setelah diperoleh potensi erosi berikutnya dilakukan klasifikasi tingkat bahaya erosi (TBE) dipengaruhi sebaran solum tanah pada unit lahan DAS, di mana solum tanah DAS krueng Langsa adalah 0 kategori dalam (BPDAS krueng Aceh). Maka sebaran tingkat bahaya erosi (TBE) diperlihatkan pada Tabel 2 berikut ini.

Tabel 2 Sebaran tingkat bahaya erosi (TBE)

\begin{tabular}{cccc}
\hline Kelas & Klasifikasi TBE & Luas (Ha) & Persentasi (\%) \\
\hline I & Sangat Ringan & $7,393.54$ & 31.354 \\
\hline II & Ringan & $2,095.88$ & 8.888 \\
\hline III & Sedang & $6,348.17$ & 26.921 \\
\hline IV & Berat & $5,682.22$ & 24.097 \\
\hline V & Sangat Berat & $2,061.21$ & 8.741 \\
\hline & Total & $\mathbf{2 3 , 5 8 1 . 0 1}$ & $\mathbf{1 0 0 . 0 0}$ \\
\hline
\end{tabular}


Tabel 2 menerangkan bahwa DAS Langsa memiliki 5 kelas TBE paling dominan berada pada TBE kelas I kategori sangat ringan seluas 7.393,54 ha atau $31,354 \%$ dari luas total DAS, disusul TBE kelas III ketegori sedang dengan luasan $6.348,17$ ha atau 26,92 \%, TBE kelas IV ketegori berat dengan luasan 5.682,22 ha atau 24,097 \%, TBE kelas II kategori ringan dengan luasan 2.095,88 ha atau 8,888 \%, dan TBE kelas V ketgori sangat berat dengan luasan 2.061,21 ha atau $8,741 \%$ sehingga berdasarkan hasil rata - rata kelas TBE pada DAS krueng Langsa masuk dalam kategori sedang dengan peta sebaran tingkat bahaya erosi diperlihatkan pada Gambar 7 berikut ini.

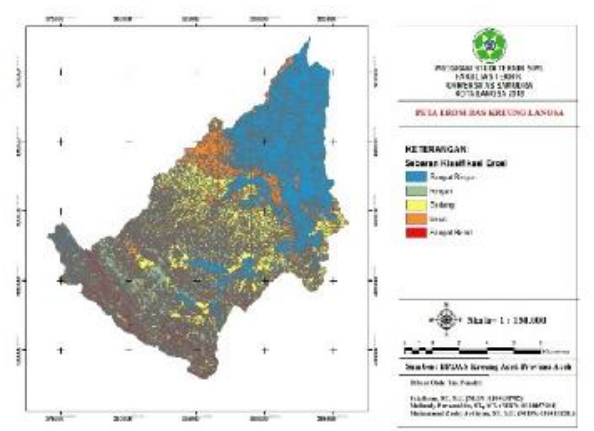

Gambar 7 Peta sebaran TBE DAS Langsa

\subsection{Sebaran Erosi Dan Sedimentasi Lahan}

Sebaran kejadian erosi setiap sub DAS paling tinggi terjadi pada sub DAS dengan kode B2 sebesar 910,29 ton/ha/tahun pada bagian hulu DAS dengan sebaran tutupan lahan perkebunan dan pertanian lahan kering memiliki tekstur tanah lempung pada kemiringan lereng rata - rata 25-45\% kategori curam, sedangkan besaran erosi yang paling rendah terjadi pada sub DAS kode I 2 sebesar 0,45 ton/ha/tahun pada bagian hilir DAS dengan sebaran tutupan lahan tambak, hutan mangrove sekunder dan tubuh air memiliki tekstur tanah lempung berdebu dan berpasir pada kemiringan lahan rata - rata adalah 0-8\% kategori datar.

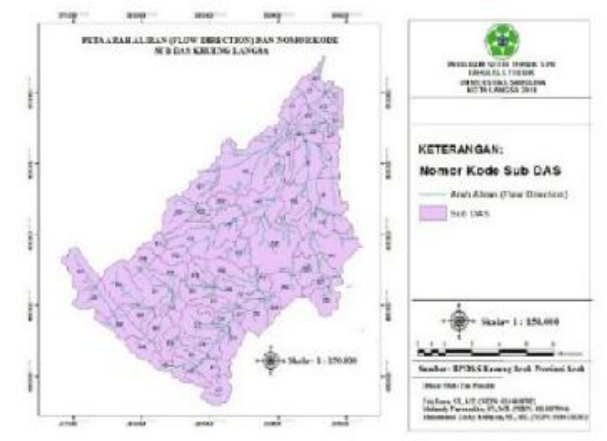

Gambar 8. Peta alur erosi dan sedimentasi lahan

Dalam proses penentuan sedimentasi lahan dan penyaluran erosi dari suatu sub DAS menuju sub DAS lainnya memerlukan suatu nilai Normalized Difference Vegetation Index (NDVI) yang berfungsi sebagai penentu pengaruh kerapatan vegetasi dari suatu sub DAS, vegetasi yang baik memiliki nilai indeks 1 dan vegetasi buruk nilai -1, sebaran NDVI dianalisa dengan SIG melalui data satelite 
landsat 8 berdasarkan pemantulan cahaya inframerah yang dihasilkan melalui persamaan (6) maka nilai NDVI pada DAS krueng Langsa berada pada rentang nilai maksimum sebesar 0,35792 dan NDVI minimum sebesar 0,0501 maka kondisi DAS memiliki sebaran vegetasi kategori sedang dengan nilai indeks vegetasi antara $0-0,5$. Sebaran NDVI diperlihatkan pada Gambar 9.

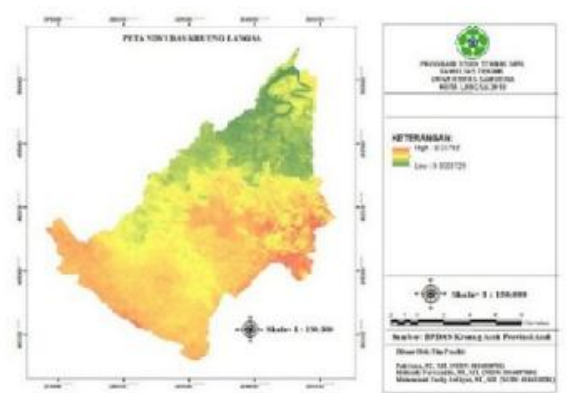

Gambar 9. Peta sebaran NDVI DAS Langsa

Di mana NDVI digunakan sebagai penentuan koefisien angkutan sedimen (KTc) sesuai dengan persamaan (7) sebagai faktor pendugaan kapasitas angkutan sedimen dalam menyalurkan erosi lahan. Nilai indeks KTc yang paling rendah sekitar 0,664 dan tertinggi sebesar 0,981 yang tersebar di setiap sub DAS yang dipakai sebagai penentuan besaran kapasitas angkutan sedimen (TC) dengan persamaan (5) akan membawa erosi keluar dari sub DAS bagian hulu yang disalurkan menuju sub DAS bagian hilir (outlet).

Proses penyaluran erosi dari setiap grid mengikuti arah aliran (flow direction) yang melintasi tiap sub DAS terlihat pada Gambar 8 dan besaran kapasitas angkutan sedimen di tiap sub DAS dapat dilihat pada Tabel 3 menjelaskan bahwa kapasitas angkutan sedimen (TC) yang paling besar terjadi pada sub DAS dengan kode J4 sebesar 98,632 ton/ha/tahun dengan kejadian erosi sebesar 0,78 ton/ha/tahun hal ini mengartikan bahwa kapasitas angkutan sedimen (TC) akan membawa semua besaran erosi sub DAS J4 akan terangkut keluar dari sub DAS, tetapi berdasarkan arah aliran sub DAS J4 menerima sumbangan erosi dari sub DAS kode I1 $\left(\mathrm{TC}_{\mathrm{I} 1}=13,304\right.$ ton/ha/tahun $)$ dan $\mathrm{I} 2\left(\mathrm{TC}_{\mathrm{I} 2}=87,996\right.$ ton/ha/tahun) menyebabkan erosi sub DAS J4 menjadi sebesar 102,079 ton/ha/tahun $\left(\mathrm{TC}_{\mathrm{I} 1}+\mathrm{TC}_{\mathrm{I} 2}+\mathrm{E}_{\mathrm{J} 4}\right)$ sehingga erosi yang keluar dari sub DAS $\left(\mathrm{T}_{\text {outJ4 }}\right.$ $=\mathrm{TC}_{\mathrm{J} 4}=98,632$ ton/ha/tahun $)$, karena erosi $\left(\mathrm{E}_{\mathrm{J} 4}=102,079\right.$ ton $/$ ha/tahun $)>$ kapasitas angkutan sedimen $\left(\mathrm{TC}_{\mathrm{J} 4}=98,632\right.$ ton/ha/tahun), sehingga ada tanah yang tererosi menjadi sedimentasi lahan di sub DAS J4 sebesar 3,447 ton/ha/tahun $\left(\mathrm{E}_{\mathrm{J} 4}-\mathrm{TC}_{\mathrm{J} 4}\right)$ di mana proses penyaluran erosi di tiap sub DAS dapat dilihat pada Tabel 8 dari hulu menuju hilir DAS krueng Langsa. besaran sedimentasi lahan yang tertinggi berada pada sub DAS B2 sebesar 908,396 ton/ha/tahun dikarenakan kapasitas angkutan sedimen pada sub DAS B2 sebesar 1,903 ton/ha/tahun dan erosi yang terjadi 910,29 ton/ha/tahun sehingga erosi yang keluar dari sub DAS $\mathrm{B} 2\left(\mathrm{~T}_{\mathrm{outB} 2}=\mathrm{TC}_{\mathrm{B} 2}\right)$ dan sisanya menjadi sedimentasi lahan. Sedangkan sedimentasi lahan yang paling rendah terjadi pada sub DAS (I1, I2, I3, I4, J2, K1, K2, K3, K4, L1, dan M1) umumnya terjadi pada bagian hilir DAS dikarenakan besaran erosi tersalurkan semuanya ke sub DAS lainnya $\left(\mathrm{E}_{\mathrm{i}}<\mathrm{TC}_{\mathrm{i}}\right)$ dengan sebaran tutupan lahan tambak, pemukiman, hutan mangrove skunder, dan tubuh air pada jenis 
tanah lempung berdebu dan lempung berpasir serta berada pada kemiringan lereng yang datar.

Tabel 3. Proses erosi dan sedimentasi lahan pada DAS Langsa

\begin{tabular}{|c|c|c|c|c|c|c|c|}
\hline \multirow{2}{*}{$\begin{array}{l}\text { Kode } \\
\text { Unit }\end{array}$} & \multirow{2}{*}{$\frac{\text { Erosi/E }}{\text { (Ton/Ha/Tahun) }}$} & \multirow{2}{*}{$\frac{\text { Tout }}{\text { (Ton/Ha/Tahun) }}$} & \multicolumn{2}{|c|}{$\begin{array}{c}\text { Arah Aliran (Flow } \\
\text { Direction) }\end{array}$} & \multirow[b]{2}{*}{$\frac{\text { Ei + Tout }}{\text { (Ton/Ha/Tahun) }}$} & \multirow{2}{*}{$\frac{\text { Tin Hilir }}{\text { (Ton/Tahun) }}$} & \multirow{2}{*}{$\begin{array}{c}\text { Sedimentasi } \\
\text { Lahan } \\
\text { (Ton/Ha/Tahun) }\end{array}$} \\
\hline & & & $\begin{array}{l}\text { Asal Sub } \\
\text { DAS }\end{array}$ & $\begin{array}{l}\text { Tujuan } \\
\text { Sub } \\
\text { DAS }\end{array}$ & & & \\
\hline A1 & 142.09 & 1.915 & & & & & 140.176 \\
\hline A2 & 343.49 & 2.155 & $\mathrm{~A} 1$ & A2 & 345.403 & 2.155 & 343.248 \\
\hline A3 & 483.21 & 3.934 & A2 & A3 & 485.366 & 3.934 & 481.433 \\
\hline A7 & 658.17 & 4.624 & & & & & 653.546 \\
\hline B1 & 573.98 & 2.111 & $\mathrm{~A} 6, \mathrm{~A} 7, \mathrm{~B} 2$ & B1 & 582.224 & 8.240 & 580.112 \\
\hline B5 & 257.54 & 1.572 & A3, B6 & B5 & 263.832 & 4.847 & 262.260 \\
\hline B6 & 228.07 & 2.363 & & & & & 225.703 \\
\hline $\mathrm{C} 1$ & 245.42 & 1.474 & B3 & $\mathrm{C} 1$ & 246.541 & 1.121 & 245.067 \\
\hline $\mathrm{C} 2$ & 122.69 & 1.130 & B4 & $\mathrm{C} 2$ & 123.826 & 1.132 & 122.696 \\
\hline $\mathrm{C} 3$ & 183.43 & 1.364 & & & & & 182.063 \\
\hline $\mathrm{C} 4$ & 309.75 & 0.913 & $\mathrm{~B} 1, \mathrm{~B} 2, \mathrm{~B} 3$ & $\mathrm{C} 4$ & 314.885 & 5.135 & 313.971 \\
\hline D1 & 152.95 & 1.657 & & & & & 151.296 \\
\hline D2 & 209.29 & 1.871 & $\mathrm{C} 3, \mathrm{C} 4$ & D2 & 211.568 & 2.277 & 209.697 \\
\hline D3 & 195.85 & 1.019 & & & & & 194.835 \\
\hline D4 & 309.32 & 2.516 & D5 & D4 & 310.268 & 0.953 & 307.753 \\
\hline D5 & 284.06 & 0.953 & $\mathrm{C} 1, \mathrm{C} 2$ & D5 & 286.668 & 2.604 & 285.714 \\
\hline D6 & 399.13 & 1.124 & & & & & 398.003 \\
\hline D7 & 223.82 & 1.769 & D1, D2, D3 & D7 & 228.365 & 4.547 & 226.595 \\
\hline D8 & 246.41 & 1.613 & D7 & D8 & 248.182 & 1.769 & 246.569 \\
\hline D9 & 74.64 & 3.296 & D4, E3 & D9 & 78.294 & & 74.998 \\
\hline E1 & 236.52 & 0.846 & D6 & E1 & 237.649 & 3.656 & 236.803 \\
\hline E4 & 150.64 & 1.537 & D9 & E4 & 153.934 & 3.296 & 152.397 \\
\hline E5 & 159.26 & 4.609 & D7, D8, E4 & E5 & 164.175 & 3.547 & 159.566 \\
\hline F1 & 140.88 & 6.219 & E5 & F1 & 145.490 & 4.609 & 139.272 \\
\hline F4 & 220.95 & 3.455 & E1, E2 & F4 & 222.665 & 1.716 & 219.210 \\
\hline F5 & 177.62 & 31.848 & & & & & 145.776 \\
\hline G1 & 160.98 & 31.340 & & & & & 129.642 \\
\hline G2 & 158.84 & 44.433 & F5 & G2 & 190.691 & 31.848 & 146.258 \\
\hline G3 & 154.63 & 24.133 & $\mathrm{G} 2$ & G3 & 199.067 & 44.433 & 174.933 \\
\hline G4 & 178.54 & 9.171 & $\mathrm{~F} 4$ & G4 & 181.997 & 31.340 & 172.826 \\
\hline G5 & 136.51 & 14.683 & $\mathrm{~F} 2, \mathrm{~F} 3$ & G5 & 149.081 & 12.569 & 134.398 \\
\hline $\mathrm{H} 3$ & 65.66 & 31.378 & & & & & 34.281 \\
\hline $\mathrm{H} 4$ & 82.60 & 21.168 & G3, G4, G5 & $\mathrm{H} 4$ & 130.590 & 47.987 & 109.422 \\
\hline $\mathrm{H} 5$ & 90.62 & 35.000 & G1 & $\mathrm{H} 5$ & 121.965 & 31.340 & 86.965 \\
\hline I1 & 13.30 & 13.304 & & & & & 0 \\
\hline $\mathrm{I} 2$ & 0.45 & 87.996 & $\mathrm{H} 3, \mathrm{H} 4, \mathrm{H} 5$ & $\mathrm{I} 2$ & 87.996 & 87.546 & 0 \\
\hline $\mathrm{I} 3$ & 0.71 & 0.712 & & & & & 0 \\
\hline I4 & 7.73 & 23.233 & $\mathrm{H} 2$ & I4 & 23.233 & 23.233 & 0 \\
\hline J1 & 1.29 & 19.603 & $\mathrm{I} 4$ & $\mathrm{~J} 1$ & 24.519 & 23.233 & 4.916 \\
\hline $\mathrm{J} 2$ & 2.03 & 2.027 & & & & & 0.000 \\
\hline J3 & 1.49 & 47.956 & $\mathrm{I} 3, \mathrm{~J} 1, \mathrm{~J} 4$ & $\mathrm{~J} 3$ & 120.440 & 118.947 & 72.483 \\
\hline $\mathrm{J} 4$ & 0.78 & 98.632 & $\mathrm{I} 1, \mathrm{I} 2$ & $\mathrm{~J} 4$ & 199.931 & 101.300 & 101.300 \\
\hline K3 & 1.70 & 3.732 & $\mathrm{~J} 2$ & K3 & 3.732 & 2.027 & 0 \\
\hline $\mathrm{K} 4$ & 1.85 & 1.854 & & & & & 0 \\
\hline L1 & 2.07 & 3.921 & K4 & L1 & 3.921 & 1.854 & 0 \\
\hline L2 & 34.89 & 20.935 & $\mathrm{~K} 1, \mathrm{~K} 2$ & L2 & 61.195 & 26.309 & 40.260 \\
\hline \multirow[t]{2}{*}{ M1 } & $\frac{1.03}{2.42}$ & 28.588 & $\mathrm{~K} 3, \mathrm{~L} 1, \mathrm{~L} 2$ & M1 & 28.588 & 28.588 & 0 \\
\hline & & \multicolumn{4}{|c|}{ Outlet (K3+L2+L1+M1) (ton/tahun) } & $10,512.25$ & \\
\hline
\end{tabular}

Distribusi erosi yang masuk ke outlet (estuari kuala Langsa) pada bagian hilir DAS (Tabel 3) di mana kejadian erosi yang keluar ke outlet adalah sebesar 
10.512,25 ton/tahun. Maka pendugaan besaran erosi yang keluar dari sub DAS dan tersalurkan pada estuari kuala Langsa sebesar 10.512,25 ton/tahun. Estuari kuala langsa akan menerima sumbangan volume sedimen akibat erosi sebesar $3.951,97 \mathrm{~m}^{3} /$ tahun, sehingga dapat dinyatakan besaran volume erosi yang masuk pada estuari kuala langsa sebesar 3.951,97 $\mathrm{m}^{3} /$ tahun kemungkinan berkontribusi terhadap pendangkalan di alur estuari kuala langsa berdasarkan luasan dari titik pertemuan aliran air krueng Langsa dengan pasang dari laut tertinggi tetapi perubahan pasut dan debit sungai Langsa tidak ditinjau dalam penelitian ini.

\section{Kesimpulan dan Saran}

\subsection{Kesimpulan}

Sebaran tingkat bahaya erosi (TBE) pada DAS krueng langsa dibagi kedalam 5 kelas TBE yaitu TBE kelas I kategori sangat ringan sebesar 31,354\%, TBE kelas III ketegori sedang sebesar 26,92\%, TBE kelas IV sebesar 24,097\%, TBE kelas II kategori ringan sebesar $8,888 \%$, dan TBE kelas V ketegori sangat berat sebesar $8,741 \%$ dari luas total DAS yaitu $23.581,01$ ha dengan rata - rata kelas TBE dalam kategori sedang

Besaran sedimentasi lahan yang tertinggi berada pada sub DAS A6 sebesar 714,096 ton/ha/tahun umumnya terjadi di hulu dan tengah DAS dan sedimentasi lahan yang paling rendah terjadi pada sub DAS (I1, I2, I3, I4, J2, K1, K2, K3, K4, L1, dan M1) umumnya terjadi pada bagian hilir DAS. Besaran erosi yang tersalurkan pada estuari kuala Langsa sebesar 10.512,25 ton/tahun atau volume erosi yang masuk pada estuari kuala langsa sebesar 3.951,97 $\mathrm{m}^{3} /$ tahun sebagai salah satu penyebab pendangkalan di alur pelayaran kuala langsa.

\subsection{Saran}

Penelitian ini perlu dilaksanakan lebih lanjut untuk melihat pengaruh besaran erosi terhadap faktor sedimen layang (suspended load) dan sedimen dasar (bed load) dalam mengkaji proses angkutan sedimen di hulu, tengah dan hilir sungai langsa serta melihat pengaruh pasut dan debit sungai akibat intensitas hujan pada DAS Langsa.

\section{Ucapan Terimakasih}

Penulis mengucapkan terima kasih kepada Ditjen Risbang Kemenristek Dikti 2018 yang telah memberikan dana penelitian dan semua pihak terkait yang telah membantu sehingga penelitian ini berjalan lancar

\section{Daftar Kepustakaan}

Arsyad.S (1989) Konservasi Tanah dan Air. Bogor: Institut Pertanian Bogor Press.

Asdak, C. (1995) Hidrologi dan Pengelolaan Daerah Aliran Sungai. Yogyakarta: Gajah Mada University Press.

Balai Pengelolaan Daerah Aliran Sungai (BPDAS) Krueng Aceh (2017). Inventaris DAS Krueng Langsa. Banda Aceh Provinsi Aceh 
Hasibuan, R. (2009) Pendugaan Erosi di Daerah Aliran Sungai (DAS) Deli dengan Metode USLE (Universal Soil Loss Equation) Berbasis Sistem Informasi Geografis (SIG). universitas Sumatera Utara.

Isma, F. (2014) Analisa Potensi Erosi Pada DAS Deli Menggunakan Sistem Informasi Geografis. Universitas Sumatera Utara.

Jain.K.M, D. . (2010) 'Estimation of Sediment Yield and Areas of Soil Erosion and Deposition for Watershed Prioritization using GIS and Remote Sensing', Springer, pp. 2091-2112. doi: 10.1007/s11269-009-9540-0.

Van Der Knijff, J. M., Jones, R. J. A. and Montanarella, L. (1999) 'Soil erosion risk assessment in Europe', Luxembourg: Office for Official Publications of the European Communities, EUR 19022(EN), p. 32 pp. Available at: http://scholar.google.com/scholar?hl=en\&btnG=Search\&q=intitle:Soil+Eros ion+Risk+Assessment+in+Italy\#0.

Rauff, A. (2011) Dasar - Dasar Pengelolaan Daerah Aliran Sungai. Edited by USU Press. Medan.

Redaksi (2018) Aceh Lanjutkan Rumah Subsidi, https://www.kasadar.com/acehlanjutkan-rumah-subsidi.

Rouse, J. W. et al. (1973) 'Monitoring vegetation systems in the Great Plains with ERTS.pdf', in 3d ERTS-1 Symp., Vol. 1, Sect. A, pp. 309-317. Available at: https://ntrs.nasa.gov/search.jsp?R=19740022614.

Suripin (2002) Pelestarian sumberdaya tanah dan air. Yogyakarta: Andi Offset.

Thomas, J., Joseph, S. and Thrivikramji, K. P. (2017) 'Author' s Accepted Manuscript Estimation of soil erosion in a rain shadow river function', International Soil and Water Conservation Research. Elsevier B.V., pp. 133. doi: 10.1016/j.iswcr.2017.12.001.

Thomas, J., Joseph, S. and Thrivikramji, K. P. (2018) 'Assessment of soil erosion in a tropical mountain river basin of the southern Western Ghats, India using RUSLE and GIS', Geoscience Frontiers. Elsevier Ltd, 9(3), pp. 893-906. doi: 10.1016/j.gsf.2017.05.011.

Tim Teknis AMDAL Khusus (2007) Kerangka Acuan Amdal Kegiatan Pengembangan Pelabuhan Kuala Langsa. Banda Aceh.

Tingkat, K. et al. (2013) 'Kajian tingkat erodibilitas beberapa jenis tanah di pegunungan baturagung desa putat dan nglanggeran kecamatan patuk kabupaten gunungkidul', Informasi, XXXIX(1), pp. 15-31.

Wischmer, W. H. and Smith, D. D. (1978) 'Predicting rainfall erosion losses: a guide to conservation planning', U.S. Department of Agriculture Handbook No. 537, pp. 1-69. doi: 10.1029/TR039i002p00285. 